\title{
PENGARUH BUDAYA SEKOLAH DAN MOTIVASI KEPALA SEKOLAH TERHADAP KINERJA GURU DI SMK MUHAMMADIYAH SE-KOTA METRO LAMPUNG
}

\author{
Wahyu Dian Nita ${ }^{1}$, Riyanto $^{2 *}$, Agus Sutanto ${ }^{3}$ \\ ${ }^{1}$ SMK Muhammadiyah 3 Metro ${ }^{, 2,3}$ Universitas Muhammadiyah Metro \\ Email: wahyudiannita@gmail.com ${ }^{l}$ \\ riyantoto56@gmail.com ${ }^{2} *$, \\ sutanto11@gmail.com ${ }^{3}$
}

\begin{abstract}
Abstrak
Guru adalah pendidik profesional yang mempunyai tugas, fungsi,dan peran penting dalam mencerdaskan kehidupan bangsa. Tujuan penelitian 1. Mengetahui pengaruh budaya sekolah terhadap kinerja guru, 2. Mengetahui pengaruh motivasi Kepala Sekolah terhadap kinerja guru. 3. Mengetahui pengaruh budaya sekolah dan motivasi Kepala Sekolah secara bersama-sama terhadap kinerja guru di SMK Muhammadiyah sekota Metro Lampung. Penelitian ini menggunakan pendekatan kuantitatif dengan proporsional random sampling. Instrumen yang digunakan adalah angket. Populasi dalam penelitian ini adalah guru yang ada di SMK Muhammadiyah se-kota Metro Lampung. Teknik analisis data menggunakan teknik regresi. Hasil dari penelitian adalah berdasarkan nilai model summary budaya sekolah $\left(\mathrm{X}_{1}\right)$ diketahui nilai $\left(\mathrm{R}^{2}\right)=0,101$, hal ini berarti bahwa variabel budaya sekolah memiliki kecenderungan sebesar 10,1\% terhadap peningkatan kinerja guru. motivasi Kepala Sekolah $\left(\mathrm{X}_{2}\right)$ diketahui nilai $\left(\mathrm{R}^{2}\right)=0,116$. Hal ini berarti bahwa variabel motivasi Kepala Sekolah memiliki kecenderungan sebesar $11,6 \%$ terhadap peningkatan kinerja guru. Secara bersama-sama di ketahui nilai $\mathrm{R}^{2}=0,116$. Hal ini berarti bahwa variasi nilai variabel $\mathrm{Y}$ yang dapat dijelaskan oleh model regresi adalah $11,6 \%$ dan selebihnya atau sebesar $88,4 \%$ variasi nilai variabel $\mathrm{Y}$ dipengaruhi oleh variabel di luar model regresi. Ada pengaruh yang positif budaya sekolah terhadap kinerja guru di SMK Muhammadiyah sekota Metro yaitu sebesar 10,1\%. Ada pengaruh yang positif motivasi Kepala Sekolah terhadap kinerja guru di SMK Muhammadiyah sekota Metro yaitu sebesar 11,6\%. Ada pengaruh yang positif budaya sekolah dan motivasi Kepala Sekolah secara bersama-sama berpengaruh terhadap kinerja guru di SMK Muhammadiyah sekota Metro yaitu sebesar 11,6\%.
\end{abstract}

Kata Kunci: Pengaruh Budaya Sekolah; Motivasi Kepala Sekolah; Kinerja Guru

\begin{abstract}
Abstrac
Teachers are professional educators who have important duties, functions and roles in the intellectual life of the nation. The research objectives 1. To determine the effect of school culture on teacher performance, 2. To determine the effect of principal's motivation on teacher performance. 3. Knowing the influence of school culture and the motivation of the principal together on the performance of teachers at Muhammadiyah Vocational Schools in the city of Metro Lampung. This study uses a quantitative approach with proportional random sampling. The instrument used is a questionnaire. The population in this study were teachers at SMK Muhammadiyah in Metro Lampung. Data analysis technique using regression technique. The results of the study are based on the value of the school culture summary model $(X 1)$, it is known that the value $(R 2)=0.101$, this means that the school culture variable has a tendency of $10.1 \%$ to increase teacher performance. The principal's motivation $(X 2)$ is known to have a value $(R 2)=0.116$. This means that the principal's motivation variable has a tendency of $11.6 \%$ to increase teacher performance. Together we know the value of $R 2=0.116$. This means that the variation in the value of the $Y$ variable that can be explained by the regression model is $11.6 \%$ and the rest or $88.4 \%$ the variation in the value of the $Y$ variable is influenced by variables outside the regression model. There is a positive influence of school culture on the performance of teachers at SMK Muhammadiyah in Metro city that is equal to 10.1\%. There is a positive influence of principal's motivation on teacher performance at SMK Muhammadiyah in Metro city, which is $11.6 \%$. There is a positive influence of school culture and the motivation of the Principal together to influence the performance of teachers at SMK Muhammadiyah in Metro City, which is 11.6\%.
\end{abstract}

Keywords: The Influence of School Culture; Principal's Motivation; Teacher Performance 


\section{PENDAHULUAN}

Kualitas pendidikan yang ada di sekolah tidak terlepas dari peranan guru. Guru adalah salah satu komponen penting dalam proses pembelajaran, oleh karena itu harus berperan aktif dan menempatkan kedudukannya sebagai tenaga professional sesuai tuntutan masyarakat yang semakin berkembang.

Kualitas proses pembelajaran sangat berkaitan erat dengan kinerja guru di sekolah, karena guru secara langsung berhadapan dengan siswa dalam pelaksanaan pendidikan. Guru merupakan pendidik profesional yang memiliki tugas utama yakni, mendidik, mengajar, membimbing, mengarahkan, melatih, menilai, dan mengevaluasi peserta didik pada jalur pendidikan formal, tugas utama itu akan efektif jika guru memiliki tingkat profesionalitas yang tercermin dari kompetensi, kemahiran, kecakapan, atau keterampilan yang memenuhi standar mutu.

Budaya sekolah turut berperan dalam peningkatan keefektifan sekolah. Budaya sekolah merupakan jiwa (spirit) sebuah sekolah yang memberikan makna terhadap kegiatan kependidikan sekolah tersebut, jika budaya sekolah lemah, maka tidak kondusif bagi sekolah. Sebaliknya budaya sekolah yang kuat maka akan menjadi pendorong bagi peningkatan mutu pendidikan, jadi sangatlah perlu untuk memahami budaya sekolah. Rendahnya mutu pendidikan pada umumnya disebabkan oleh buruknya budaya sekolah, karena lembagalembaga pendidikan seperti sekolah belum memahami budaya yang ada di sekolah mereka, bahkan menganggap bahwa budaya itu tidak penting. Budaya sekolah yang harus diterapkan antara lain, budaya disiplin, menjunjung tinggi norma-norma budaya membaca, kerjasama, menunjukkan sikap positif dan melakukan kebiasaan yang mendukung program sekolah.

Kepala sekolah merupakan faktor penentu dalam mengelola pendidikan di sekolah demi tercapainya tujuan pendidikan, oleh karena itu kepala sekolah dituntut untuk mempunyai pengetahuan, kemampuan, dan keterampilan yang memadai. Kepala sekolah berperan sangat penting, karena kepala sekolah lebih dekat dan langsung berhubungan dengan pelaksanaan program pendidikan di sekolah.

Kuat dan lemahnya motivasi kepala sekolah terhadap guru di sekolah ikut menentukan besar kecilnya prestasi atau kinerjanya. Dengan demikian seorang pemimpin dalam hal ini adalah kepala sekolah penting untuk memberikan perhatian kepada bawahan, untuk menciptakan kegairahan kerja seseorang agar mereka mau bekerjasama, bekerja efektif dan mencapai kepuasan. Kepala sekolah hendaknya mampu memotivasi dan menggerakkan guru untuk melaksanakan tugas atau pekerjaannya secara bergairah, aktif, dinamis, dan berkreasi. Membangkitkan motivasi serta dapat membuka kesadaran sikap, dan menjadi pintu masuk bagi perbaikan dan kemajuan sekolah.

Berdasarkan prasurvei di SMK Muhammadiyah sekota Metro Lampung ditemukan beberapa permasalahan yaitu

1. Minimnya kinerja dari guru yang berada di sekolah tersebut, dimana masih ada beberapa guru yang kurang profesional dan bertanggungjawab dalam menjalankan tugasnya sebagai tenaga pengajar dan tenaga kependidikan.

2. Masih terdapat guru yang kurang disiplin dalam menjalankan tugasnya ketika kepala sekolah tidak berada di tempat.

3. Masih ada guru yang belum maksimal dalam menerapkan budaya sekolah yang baik yang berpengaruh terhadap kinerja guru. 
4. Budaya sekolah masih belum terlihat dikalangan guru dan siswa sehingga berdampak pada kinerja guru.

5. Kepala sekolah belum mampu memotivasi jajarannya dengan baik sebagai contoh belum ada penghargaan terhadap guru yang berprestasi. Serta belum mampu menciptakan kerja sama yang efektif, dan kooperatif.

Kinerja merupakan hasil kerja secara kualitas dan kuantitas yang dicapai oleh seorang pegawai dalam melaksanakan tugasnya sesuai dengan tanggung jawab yang diberikan kepadanya. Kinerja sebagai upaya yang dilakukan dalam penyelesaian pekerjaan untuk menghasilkan keluaran dalam periode tertentu. Kinerja guru dipengaruhi juga oleh kepuasan kerja yaitu perasaan individu terhadap pekerjaan yang memberikan kepuasan batin kepada seseorang sehingga pekerjaan itu disenangi dan digeluti dengan baik.

Menurut Smith (dalam Sedarmayanti, 2010:5) menyampaikan bahwa "kinerja merupakan hasil atau keluaran dari suatu proses". Sedangkan Wirawan (2015: 5) mengemukakan bahwa "kinerja adalah keluaran yang dihasilkan oleh fungsi-fungsi atau indikator-indikator suatu pekerjaan atau suatu profesi dalam waktu tertentu". Menurut Arifin \& Barnawi, (2017: 13) menyatakan bahwa "Kinerja adalah tingkat keberhasilan sesorang atau kelompok dalam melaksanakan tugas sesuai tanggung jawab dan wewenangnya berdasarkan standar kinerja yang telah ditetapkan selama periode tertentu dalam kerangka mencapai tujuan organisasi”.

Menurut Undang-Undang Nomor 14 Tahun 2005 tentang Guru Dan Dosen menjelaskan tentang guru. Guru adalah pendidik profesional dengan tugas utama mendidik, mengajar, membimbing, mengarahkan, melatih, menilai, dan mengevaluasi peserta didik pada pendidikan anak usia dini jalur formal, pendidikan dasar, dan menengah. Menurut Supardi (2016: 54) mengatakan bahwa "Kinerja guru merupakan kemampuan seorang guru dalam melaksanakan tugas pembelajaran di madrasah dan bertanggung jawab atas peserta didik di bawah bimbingannya dengan meningkatkan prestasi belajar peserta didik".

Kinerja guru juga dapat diartikan sebagai suatu kondisi yang menunjukkan kemampuan seorang dalam menjalankan tugasnya di madrasah/sekolah serta menggambarkan adanya suatu perbuatan yang ditampilkan guru dalam atau selama melakukan aktivitas pembelajaran.Kinerja guru mempunyai spesifikasi tertentu. Kinerja guru dapat dilihat dan diukur berdasarkan spesifikasi atau kriteria kompetensi yang harus dimiliki oleh setiap guru. Berkaitan dengan kinerja guru, wujud perilaku yang dimaksud adalah kegiatan guru dalam proses pembelajaran. Sedangkan menurut Mulyasa (2013: 88), "Kinerja guru diartikan sebagai suatu upaya untuk memperoleh gambaran tentang pengetahuan, ketrampilan, nilai, dan sikap guru dalam melaksanakan tugas dan fungsinya, yang ditunjukkan dalam penampilan, perbuatan, prestasi kerjanya".

Dalam UU Republik Indonesia No 20 Tahun 2003 tentang Sisdiknas pasal 39 ayat (2), menyatakan bahwa "Pendidik merupakan tenaga profesional yang bertugas merencanakan dan melaksanakan proses pembelajaran, menilai hasil pembelajaran, melakukan pembimbingan dan pelatihan serta melakukan penelitian dan pengabdian kepada masyarakat, terutama bagi pendidik pada perguruan tinggi".

Menurut Juhri (2010: 34) "kebudayaan adalah hasil cipta dan karya manusia berupa norma-norma, nilai-nilai, kepercayaan, tingkah laku, dan teknologi yang dipelajari dan dimiliki oleh semua anggota masyarakat tertentu." Konsep tersebut menekankan pada unsurunsur yang terdapat di dalam budaya sekolah yang dijadikan sebagai sistem nilai seluruh 
anggota komunitas sekolah. Pendidikan pada dasarnya adalah proses psikologis anak terhadap rangsangan ekternal dari kondisi yang sifatnya alamiah, terjadi spontan sebagai manifestasi budaya guru dan siswa secara umum dan kondisi yang diciptakan oelh sekolah dan guru dalam proses belajarnya, Setiap anak di sekolah selalu bersama dan berinteraksi dengan anak lainnya juga bersama dengan guru dengan membawa serta budayanya masingmasing selain budaya umum yang dimiliki oleh semua anak dan guru.

Pendapat Schein, sebagaimana dikutip Deal dan Peterson (1999) dalam Zamroni (2016 : 44) menyatakan bahwa Kultur sekolah merupakan keseluruhan yang unik, gagasangagasan, kebiasaan-kebiasaan, asumsi-asumsi, harapan-harapan bersama, nilai-nilai, normanorma yang dipegang bersama dan menentukan bagaimana warga sekolah berpikir dan bertindak. Kebiasaan-kebiasaan dan nilai-nilai yang diterapkan di dalam sekolah, "merupakan budaya sekolah". Budaya dan budaya sekolah bukanlah suatu sistem yang lahir sebagai aturan yang logis atau tidak lingkungan sekolah, tetapi budaya sekolah dan budaya sekolah harus lahir dari lingkungan suasana budaya yang mendukung seseorang melaksanakan dengan penuh tanggung jawab, rela, alami, dan sadar bahwa apa yang dilakukan (ketaatan itu muncul dengan sendirinya tanpa harus menunggu perintah atau dibawah tekanan) merupakan spontanitas berdasarkan kata hati karena didukung oleh budaya lingkungan yang menciptakan kesadaran kita dalam lingkungan sekolah.

Menurut Mulyadi (2010:91-92) bahwa "Budaya sekolah merupakan karakteristik khas sekolah yang dapat diidentifikasi melalui nilai yang dianutnya, sikap yang dimilikinya, kebiasaan-kebiasaan yang ditampilkannya, dan tindakan yang ditunjukan oleh seluruh personel sekolah yang membentuk suatu kesatuan khusus dari sistem sekolah".

Aan Komariah dan Triatna (2010:102) menyatakan bahwa "budaya sekolah adalah keseluruhan nilai-nilai dan norma- norma yang dianut sekolah yang meliputi: visi, misi, dan tujuan sekolah, etos belajar, integrasi, norma agama, norma hukum dan norma sosial".

Menurut Mangkunegara (2017:81) pengertian motivasi sebagai berikut: "motivasi merupakan kondisi atau energi yang menggerakan diri karyawan yang terarah atau tertuju untuk mencapai tujuan organisasi perusahaan." Setiap individu memiliki kondisi internal, dimana kondisi internal tersebut turut berperan dalam aktivitas dirinya sehari-hari. Salah satu dari kondisi internal tersebut adalah motivasi, motivasi kerja sangat diperlukan agar bisa memberikan dan melayani yang terbaik pada pekerjaan.

Motivasi adalah dorongan dasar yang menggerakkan seseorang bertingkah laku. Dorongan ini berada dalam pada diri seseorang yang menggerakkan untuk melakukan sesuatu yang sesuai dengan dorongan dalam dirinya. Oleh karena itu, perbuatan seseorang yang didasar atas motivasi tertentu mengandung tema sesuai dengan motivasi yang mendasarinya

Seseorang memerlukan motivasi agar orang tersebut mau melakukan suatu pekerjaan. Hasibuan (2006: 146) menyatakan "tujuan motivasi antara lain sebagai berikut 1) Meningkatkan moral dan kepuasan kerja karyawan, 2)Meningkatkan produktivitas kerja karyawan, 3) Mempertahankan kestabilan karyawan perusahaan, 4) Peningkatan kedisiplinan karyawan, 5) Mengefektifkan pengadaan karyawan, 6) Menciptakan suasana dan hubungan kerja yang baik, 7) Meningkatkan loyalitas, kreativitas, dan partisipasi karyawan, 8) Meningkatkan tingkat kesejahteraan karyawan, 9) Mempertinggi rasa tanggung jawab karyawan terhadap tugas-tugasnya, 10) Meningkatkan efisiensi penggunaan alat-alat dan bahan baku." 


\section{METODE PENELITIAN}

Jenis penelitian yang digunakan dalam penelitian ini adalah penelitian kuantitatif dengan menggunakan metode asosiatif. Penelitian ini meliputi dua variabel bebas budaya sekolah dan motivasi kepala sekolah serta satu variabel terikat yaitu kinerja guru. Populasi dalam penelitian ini adalah guru SMK Muhammadiyah sekota Metro Lampung. Berdasarkan data yang ada, di sekolah dan guru SMK Muhammadiyah sekota metro berjumlah 219 orang guru kemudian dengan teknik sampling proportional random sampling diambil sampel sebanyak 66 guru. Instrumen yang digunakan dalam penelitian ini adalah angket. Metode pengumpulan data menggunakan angket dan dokumentasi. Teknik analisis data menggunakan teknik analisis statistik dan teknik analisis deskriptif.

\section{HASIL DAN PEMBAHASAN}

Berdasarkan hasil penelitian di lapangan dan analisis data yang telah dilakukan, maka dapat di bahas mengenai hal-hal dibawah ini:

\section{Pembahasan Variabel Budaya Sekolah dan Motivasi Kepala Sekolah dengan Kinerja Guru}

\section{a. Budaya Sekolah}

Menurut Mulyadi (2010:91-92) bahwa "Budaya sekolah merupakan karakteristik khas sekolah yang dapat diidentifikasi melalui nilai yang dianutnya, sikap yang dimilikinya, kebiasaan-kebiasaan yang ditampilkannya, dan tindakan yang ditunjukan oleh seluruh personel sekolah yang membentuk suatu kesatuan khusus dari sistem sekolah".

Berdasarkan hasil analisis data yang telah dilakukan diperoleh data mengenai budaya sekolah yaitu diperoleh skor terendah 62 tertinggi 104, skor rata-rata 81,727 dan standar deviasi 11,12. Skor-skor tersebut diperoleh berdasarkan hasil penskoran angket yang terdiri dari 25 item pernyataan dengan 5 alternatif jawaban. Budaya sekolah memberikan sumbangan sebesar $10,1 \%$ terhadap kinerja guru. Dengan demikian dapat dikatakan bahwa budaya sekolah mempengaruhi perilaku guru dalam melaksanakan tugas pembelajaran.

\section{b. Motivasi Kepala Sekolah}

Berdasarkan hasil analisis diperoleh skor tertinggi yang diperoleh skor terendah 38, tertinggi 65, skor rata-rata 40,7 dan standar deviasi 6,0467. Skor-skor tersebut diperoleh berdasarkan hasil penskoran angket yang terdiri dari 15 item pernyataan dengan 5 alternatif jawaban. Hasil penelitian menunjukan bahwa motivasi kepala sekolah memberikan sumbangan sebesar 11,6\% terhadap kinerja guru, dengan demikian dapat juga dikatakan bahwa motivasi kepala sekolah akan berhubungan kinerja seseorang yang ada di sekolah. hasil ini sesuai dengan hasil penelitian relevan sebelumnya yaitu menurut Avandi (2021) bahwa motivasi kepala sekolah berpengaruh terhadap kinerja guru. Hal ini diperkuat dengan pendapat Hasibuan (2006: 146) menyatakan "tujuan motivasi antara lain sebagai berikut 1) Meningkatkan moral dan kepuasan kerja karyawan, 2)Meningkatkan produktivitas kerja karyawan, 3) Mempertahankan kestabilan karyawan perusahaan, 4) Peningkatan kedisiplinan karyawan, 5) Mengefektifkan pengadaan karyawan, 6) Menciptakan suasana dan 
hubungan kerja yang baik, 7) Meningkatkan loyalitas, kreativitas, dan partisipasi karyawan, 8) Meningkatkan tingkat kesejahteraan karyawan, 9) Mempertinggi rasa tanggung jawab karyawan terhadap tugas-tugasnya, 10) Meningkatkan efisiensi penggunaan alat-alat dan bahan baku.

\section{c. Kinerja Guru}

Menurut Smith (dalam Sedarmayanti, 2010:5) menyampaikan bahwa "kinerja merupakan hasil atau keluaran dari suatu proses". Sedangkan Wirawan (2015: 5) mengemukakan bahwa "kinerja adalah keluaran yang dihasilkan oleh fungsi-fungsi atau indikator-indikator suatu pekerjaan atau suatu profesi dalam waktu tertentu". Menurut Arifin \& Barnawi, (2017: 13) menyatakan bahwa "Kinerja adalah tingkat keberhasilan sesorang atau kelompok dalam melaksanakan tugas sesuai tanggung jawab dan wewenangnya berdasarkan standar kinerja yang telah ditetapkan selama periode tertentu dalam kerangka mencapai tujuan organisasi".

Berdasarkan hasil analisis mengenai kinerja guru SMK Muhammadiyah sekota metro diperoleh skor terendah 66 tertinggi 107, skor rata-rata 73,8 dan standar deviasi 15,507. Skor-skor tersebut diperoleh berdasarkan hasil penskoran angket yang terdiri dari 25 item pernyataan dengan 5 alternatif jawaban. Skor ini menunjukkan rata-rata guru di SMK mempunyai kinerja yang baik. Hasil analisis skor angket menunjukkan bahwa dalam pelaksanaan pembelajaran, guru-guru SMK Muhammadiyah sekota Metro sudah melaksanakannya dengan baik.

\section{d. Hubungan budaya sekolah dan motivasi kepala sekolah secara bersama-sama terhadap kinerja guru}

Selanjutnya uji hipotesis, berdasarkan hasil analisis regresi linier ganda diperoleh nilai konstanta $a_{0}=57,229$ dan koefisien $b_{1}=0,18, b_{2}=0,367$, dengan demikian dapat dirumuskan persamaan regresi linier ganda pengaruh budaya sekolah $\left(\mathrm{X}_{1}\right)$, dan motivasi kepala sekolah $\left(\mathrm{X}_{2}\right)$ terhadap kinerja guru Muhammadiyah sekota Metro (Y) dengan persamaan $\hat{Y}=57,229+0,18 \mathrm{X}_{1}+0,367 \mathrm{X}_{2}$. Hal ini menunjukan bahwa ada keterkaitan antara kinerja guru $(\mathrm{Y})$ dengan budaya sekolah $\left(\mathrm{X}_{1}\right)$, dan motivasi kepala sekolah $\left(\mathrm{X}_{2}\right)$ guru SMK Muhammadiyah sekota Metro. Tingkat ketergantungan variabel kinerja guru terhadap variabel budaya sekolah, dan motivasi kepala sekolah ditunjukan oleh nilai $\mathrm{R}^{2}=0,116$, yang berarti $11,6 \%$ nilai kinerja guru ditentukan secara bersama-sama oleh nilai variabel budaya sekolah dan motivasi kepala sekolah dan sisanya $88,4 \%$ dipengaruhi oleh variabel lain.

Beberapa kelemahan dan keterbatasan dalam penelitian ini yang dapat diidentifikasi sebagai berikut:

1. Jumlah variabel dalam penelitian ini hanya diambil dua, sedangkan variabel yang mempengaruhi kinerja guru lebih dari dua, sehingga karena keterbatasan variabel yang digunakan, maka hasil penelitian ini belum dapat merepresentasikan variabel-variabel lain yang berpengaruh terhadap kinerja guru.

2. Penelitian ini mengungkap kinerja guru yang dipengaruhi oleh dua faktor saja, yaitu faktor budaya sekolah dan faktor motivasi kepala sekolah, sedangkan 
faktor-faktor lain yang mempengaruhi kinerja guru sangat kompleks dan tidak diungkap dalam penelitian ini. Sehingga diharapkan untuk penelitian selanjutnya dapat mengungkap kinerja guru berdasarkan faktor-faktor lain.

3. Jumlah sampel yang relatif terbatas hanya pada SMK Muhammadiyah sekota Metro Lampung, sehingga validitas eksternal penelitian juga terbatas, artinya penulis tidak menjamin hasil penelitian ini berlaku pada kelompok yang lebih luas apalagi menjangkau SMK yang ada kabupaten/kota se-provinsi Lampung yang memiliki kondisi yang berbeda antara daerah yang satu dengan yang lainnya.

4. Instrumen yang dipergunakan untuk mendapatkan data meskipun telah divalidasi dan diujicobakan sebelumnya, belum dapat dijadikan satu-satunya instrumen yang dapat mengungkapkan keseluruhan aspek yang diteliti mengingat banyaknya prediktor yang dapat dikaitkan dengan tinggi rendahnya budaya sekolah, motivasi kepala sekolah dan kinerja guru.

5. Keterbatasan dalam penelitian ini adalah menggunakan angket sebagai alat pengukuran variabel penelitian,peneliti tidak melakukan wawancara atau survei pada saat diadakan pelatihan, sehingga simpulan yang diambil hanya berdasarkan pada data yang dikumpulkan melalui penggunaan instrumen secara tertulis.

Berdasarkan hasil penelitian dan analisis data, penulis memberikan beberapa rekomendasi sebagai berikut ;

1. Budaya sekolah yang diterapkan dengan baik dan mengarah kepada hal yang positif akan menghasilkan peningkatan kinerja guru baik dalam melaksanakan pembelajaran ataupun hubungan siswanya serta dapat memberikan contoh pola nilai, norma, sikap dan kebiasaan baik yang akan ditiru oleh siswa.

2. Kepala sekolah harus berusaha meningkatkan kemampuan di berbagai bidang untuk dapat memotivasi dan menginspirasi guru maupun staff dan ketrampilan dalam berkoordinasi dan semangat dalam mencapai visi misi lembaga.

3. Kinerja dari seorang guru seorang guru adalah penentu keberhasilan pendidikan di sekolah. Meningkatkan kinerja adalah tanggungjawab dari anggota-anggota sekolah, tidak hanya guru saja melainkan kepala sekolah. Masing -masing sudah memiliki tugas dan tanggung jawabnya tersendiri.

\section{KESIMPULAN}

Berdasarkan tujuan dan hasil analisis data pada uraian sebelumnya, maka padat disimpulkan bahwa terdapat pengaruh yang positif antara budaya sekolah dan motivasi kepala sekolah terhadap kinerja guru SMK Muhammadiyah sekota Metro yaitu sebesar $11,6 \%$. Hal ini berdasarkan perhitungan persamaan regresi yang menggambarkan bahwa kenaikan secara bersama-sama dari skor budaya sekolah dan skor motivasi sekolah berkecenderungan diikuti oleh kenaikan skor kinerja guru, sehingga secara kuantitatif jika kedua variabel bebas tersebut dihubungkan secara bersama-sama terhadap variabel terikat, maka budaya sekolah memberikan kontribusi sebesar 0,18 dan Motivasi Kepala Sekolah memberikan kontribusi sebesar 0,367 terhadap kinerja guru pada arah positif dengan konstanta 57,229. 


\section{DAFTAR PUSTAKA}

Avandi, Nanang., Sudirman Aminin, Nyoto Suseno. (2021). Pengaruh Kepemimpinan Kepala Sekolah Dan Motivasi Kerja Terhadap Kinerja Guru Di Smp Se-Kecamatan Banjar Baru Kabupaten Tulang Bawang. Jurnal POACE. Vol 1 No 1. https://doi.org/10.24127/poace.v1i1.615.

Sedarmayanti, (2010). Sumber Daya Manusia dan Produktivitas Kerja, cetakan kedua, penerbit: Mandar Maju. Bandung.

Wirawan, (2015). Evaluasi Kinerja Sumber Daya Manusia (Teori, Aplikasi, dan Penelitian). Jakarta: Salemba Empat.

Arifin, Muhammad \& Barnawi. (2012). Kinerja Guru Profesional, Instrumen Pembinaan, Peningkatan \& Penilaian, Yogyakarta: Ar-Ruzz Media.

Undang-Undang Republik Indonesia Nomor 14 Tahun 2005 tentang Guru dan Dosen Pasal 10.

Supardi. (2016). Kinerja Guru. Jakarta: PT Raja Grafindo Persada.

Mulyasa. (2013). Uji Kompetensi dan Penilaian Kinerja Guru. Bandung: PT Remaja Rosda karya.

Undang-Undang Republik Indonesia Nomor 20 Tahun 2003 Tentang Sistem Pendidikan Nasional

Juhri. (2010). Landasan Dan Wawasan Pendidikan: Suatu Pendekatan Kompetensi Guru. Jakarta: Panji Grafika.

Zamroni. (2016). Kultur Sekolah. Yogyakarta : Gavin Kalam Utama

Mulyadi. (2010). Kepemimpinan Kepala Sekolah dalam Mengembangkan Budaya Mutu. Malang: UIN Maliki Press

Aan Komariah dan Cepi Triatna, (2006). Visionary Leadership; Menuju Sekolah Efektif, Jakarta: Bumi Aksara.

Mangkunegara, A.A. Anwar Prabu. (2017). Manajemen Sumber Daya Manusia Perusahaan, Bandung : Remaja Rosdakarya. 